\title{
Corporate Governance in Policing: Standards and Ethics
}

\author{
Ronald Francis and Anona Armstrong \\ Victoria University, Australia
}

\begin{abstract}
The purpose of this paper is twofold: one is to canvass some issues relating to corporate governance for police work, particularly to emphasise the importance of expressing appropriate values. The second point is to illustrate that suggestion by providing examples of strategic governance issues of importance for police functioning: these latter points derive from the principles of corporate governance, and from the behavioural sciences. The conclusion is drawn that as policing is a constantly evolving process and organisation that can and should learn from recent developments. The paper also argues that the values expressed in a Code of Ethics are vital to efficient and moral functioning, and invests the principles of governance with both meaning and a means of judging the worth of such principles. The concept of paradoxical cause is mentioned in outline. It is designed to alert practitioners to issues which may be counterproductive in implementation. Five moderate suggestions are itemised and documented which are: the importance of the formal rules for meetings; using the strategies proposed by master strategists; the importance of having an ethical infrastructure; in discussions and debates the importance of separating issues from personality; and the setting of key performance indicators for assessing success.
\end{abstract}

\section{Keywords}

Strategic Corporate Governance, Code of Ethics, Policing

\section{Introduction}

The purpose of this paper is to address the impact of the value of corporate governance on police standards and on police practice. It argues that sensitivity to ethics is crucial to both efficient functioning and to reputation. Modern policing is not so much a fixed entity as an evolving set of functions and values. As such attention to mission statements, to governance, and to ethics is essential.

Evolving police work came, inevitably, to be seen as both generalist and specialist. Thus the ordinary foot patrols had specialist functions added: among them were the mounted police, the water police, the air wing, the dog squad, the drugs squad, and homicide. Police come in various forms: semi-military,

Copyright (C) 2008 Victoria University. This document has been published as part of the Journal of Business Systems, Governance and Ethics in both online and print formats. Educational and non-profit institutions are granted a nonexclusive licence to utilise this document in whole or in part for personal or classroom use without fee, provided that correct attribution and citation are made and this copyright statement is reproduced. Any other usage is prohibited without the express permission of the secret, political, military, religious, community, and secular civic control. The civil guard originally had various functions that have since separated (such as fire control). The invention of policing went hand-in-hand with the development of the notion of due process and of civil liberties. The point here is to emphasise that policing, like all other social functions, is a constantly evolving process; and one which 
has intimate connections to other parts of our social system (such as politics and the judicial system).

Corporate governance has, underlying it, both legislation and of ethical principles. The role of police has connections to very many other legislated matters. It is interesting to observe that if Victorian legislation is searched for Acts which are police relevant, there are 201. They cover a broad spectrum that includes witness-protection, the magistrates court act, seafood, and gambling. The main Act seems to be the 1958 Police Regulation Act (version 105). It is worthy of note that the Act does not have a mission statement such as the '... purpose of a police force is ...'. Perhaps that is seen as too constricting: whatever the reason it would be good to see a high level aim given explicit expression.

\section{Governance Issues}

The general approach taken here is that of analysis rather than empirical evidence. The value of this approach is seen to be one in which governance in a quasi-military organisation may be viewed not only for its own sake but also as a means of throwing light on governance in general. The findings of this analysis are believed to have wider application, being derived from governance considerations rather than from a specific empirical study.

Police governance is of various forms. First there is the Act that sets up and sanctions a police force: in Victoria, for example, it is the 1958 Police Regulation Act. That enabling legislation and, in its ideal form, is one of general control rather than control of particular issues. Thus a government would set up and fund a police force, provide the necessary general support, but not instruct the Commissioner on how to do the job, nor would it interfere in particular cases. Governments do, however, take account of issues that emerge, and legislate accordingly.

One form of governance is that of internal control within the force itself. Among other things this takes the form of the regulation of conduct, internal procedures, the Office of Police Integrity, and the information flow both up and down. Yet another form is that of how the public are to be treated. This involves reference to principles such as court procedures and requirements, the use of courtesy, the presumption of innocence, and the separation of powers. Finally, there is an emerging form of governance - that of research governance.

In Victoria, a fairly typical Australian state, the chain of governance is that the Chief Commissioner reports directly to the Minister of Police. As the official statement holds: 'the Corporate Committee has responsibility for setting corporate policy positioning, setting strategic direction and policy, organisational performance targets, corporate budget and for monitoring organisational performance. It also has the responsibility of mentoring the various departments and developing senior staff'. That corporate committee has six standing committees, each has its own terms of reference and charter, and each is responsible for the development and oversight of core strategies and projects in their own area.

\section{In praise of corporate governance}

One of the most persuasive arguments for corporate governance is that it provides stability as well as conforming to values. It is worth noting that stability is an essential part of organisational conduct. Standard accounting procedures, corporate regulators, the stock exchange, and banking processes are all instances of stability in commerce. Regularity and a reasonable degree of predictiveness are highly desirable qualities.

Perhaps a significant additional contribution that good corporate governance provides is that of both reducing the incidence of, and providing solutions for, whistleblowing. Some may believe that instituting ethics policies and procedures sensitises employees to ethical matters and, thereby, fosters a climate of whistleblowing. While we have no firm evidence for such a belief we may conclude that a well ordered organisation is less likely to have problems if the commitment to good governance is strict. Good governance principles also provide a reference point by which breaches may be judged, and hence make the resolution of disputes easier. To that end a whistleblower policy is a substantial help. 


\section{Ethical Issues}

The law gives police extraordinary powers and, at the same time, circumscribes those powers in a manner that ensures that they are not abused. This form of expression of the doctrine of the separation of powers not only ensures that power is not abused but also has the consequence of enhancing the reputation of the police as a fair-dealing body. It is the very values that underlie police governance that ensure it.

One of the often unexpressed problems with morals is that it is not measurable. The values that people do have may, however, be assessed with a modicum of precision by using various scaling techniques commonly used in the behavioural sciences. That point of being able to assess is also true of broader concepts such as 'ethical climate'

\section{Ethics, morals and the law}

The general issue of the relationship between morals and the law was the subject of an extended debate in the UK in the 1960s, known as the Hart-Devlin debate. Lord Devlin's original paper compared morals and torts, and distinguished between those things that are wrong in themselves (e.g. those things which impinge on the sanctity of life), and those things that are wrong because they are prohibited (e.g. a minor breach of a trading act). As Devlin (1963) wrote, 'real crimes are sins with legal definition'. Devlin's view is that lawmakers need the stuff of morals in order to fashion the law .

That view was contested by Professor Hart of Oxford (1987), who noted that it is not possible for a community as large and diverse as the UK to have a firm and unambiguous moral position. The supposedly common stock of ideas on right and wrong do not exist, a point that has even greater force in countries that are yet more socially pluralistic.

No matter that there might be diversity of opinion - that interchange is about values, and reveals the importance that values-debates play. What is most evident is that any principle of corporate governance can only be evaluated for worth if there is a standard by which it may be judged.

\section{The argument in favour of codes}

Codes have specific application. The code of practice for medical practitioners does not apply to lawyers: the police are bound by the police codes. That specific application is captured in The Australasian Police Practice Standards as:

- Ethical practice

- Professional service delivery

- Knowledge-based practice

- Continuing competence

- Professional responsibility and accountability

Prominent here is the ongoing nature of police, of continual updating, and of the critical issue of accountability. Such principles are at the top of the hierarchy, followed by strategic issues, with tactical issues being further down, and day-to-day operational matters being the guide for police work at the primary face.

\section{Human Values, Ethics and Corporate Governance}

Human values inevitably invest corporate governance decisions. The notion that we stop sending small boys up chimneys to clean them does not have its origins in economics but, rather, in the physical danger, degradation, and exploitation. In addition to the direct links to business, and such questions as 'Is ethics profitable?', there is the issue of the whole framework in which we work. No matter how good it is for the economy we do not agree that child labour is humane or just: no matter what the economic justifications we do not agree that unsafe work practices are acceptable. In just the same way one would 
not wish to have police so efficient at catching criminals that they erred on the side of wrongful arrests. These sorts of issues are now part of the fabric of our thinking and are not questioned. So many such issues are such a part of our frame of reference that we no more notice them than a fish notices water.

The unfettered use of power is against common and widely accepted covenants, such as the United Nations Declaration of Human Rights, and against the precepts of the world's major religions. Privileges carry corresponding responsibilities. One cannot imagine admiring any social institution which takes upon itself all of the benefits without acknowledging and adopting corresponding responsibilities. Similarly, organisations operate within a wider social framework that gives them life, and sustains their activities. It is this debt which business repays to society by making the lives of its citizens that much better. These wider responsibilities find expression in various ways: by economic betterment, by health and educational improvements, by corporate philanthropy, and by operating within a structured framework of values.

\section{Self Regulation}

Ethical self regulation is a complement to the law - it is not in competition. While the law very properly sets minimum standards and sanctions transgressions, ethics complements that by being positive rather than punitive. It is about being solution-oriented rather than judgemental. The trend to self regulation has much to commend it, and may be materially assisted by adopting the Australian Standards on Corporate Governance, having been worked out in detail. This developed model owes much to other approaches (such as the OECD code) but has particular value in Australia, and is applicable to a variety of organisations from the commercial to the voluntary. Among the pressing arguments for adopting a code of corporate governance is that where self regulation fails, where organisations are driven by minimum standards, the law will intervene. That intervention is costly in time, money, and in reputational damage.

Verbal definitions often confuse what we do. There is, clearly, a world of difference between healthdamaging exploitative slavery on the one hand, and recruiting from another country cheap contract labour. It is so easy to fall into the comfortable position of assuming the superiority of the ways with which we are most familiar and becoming moral imperialists. It is well to remind ourselves yet again that cultural variations tend to distract us from the very real differences that exist within our own society. Cultures do not come as an invariant unit. The guidelines that apply to inter-cultural interchange can apply with equal force to dealing with the substantial personality variations that we see in our own everyday lives.

The treatment of stakeholders as cypher entities instead of human beings is most likely to result in a failure to achieve organisational goals. The harsh treatment of personnel does not promote productivity. The promotion of goodwill is an instance of treating stakeholders as dignified and sensible people; it not only promotes organisational efficiency, but also results in goodwill in commercial terms that may have a substantial monetary value.

\section{Police Codes}

It is pleasing to see that the Victoria Police have a self imposed code: interestingly it uses a useful mnemonic to remind the busy practitioner of the four basic principles.

Will your decision stand scrutiny? S

Is your decision ethical?

Is your decision lawful?

Is your decision fair? $\quad$ F

Importance now attaches to the notion of integrity as an essential ingredient of policing. The introduction of the Office of Police Integrity in the state of Victoria is a concrete expression of that recognition. Formed in late 2004, the Office is the monitor of high ethical standards and, at a practical 
level, handles complaints against the police and conducts investigations into police corruption. The standards that prevail rightly include the concept of natural justice. The Manual puts those points precisely.

\section{Paradoxical cause}

In dealing with governance issues, and acting from the best of motives, it is quite possible that a proposed policy or intervention may be self-defeating. Some police-related instances are: the construction of physical barriers may invite destruction; high speed chases may result in the injury they are designed to prevent; the use of suspended sentences in the UK was designed to keep the prison populations down. As a suspended sentence was not perceived as a punishment, it did not have the desired deterrent effect. Re-offenders collected their original sentence and the new one - thereby filling the prisons.

The recent declarations by governments that we need to be deprived of some of our civil liberties in order to protect our way of life has become more pressing. It does have the curious conclusion that we need to be deprived of something in order to protect the thing of which we are deprived. There may be pressing reasons to suspend some civil liberties in order to protect others - but it is a judgement that is fraught with difficulty in that it may end up destroying the very thing that one wishes to preserve.

In ethics there is the now recognised conclusion that to try and capture ethics into a series of compliance acts is often counter-productive. Ticking the correct boxes leads to a mind-set of doing minor compliance acts rather than attending to higher principles. When the correct boxes have been ticked then there might be a switch-off for values leading to lower ethical standards.

A rise in complaints against the police may reflect an increasing dissatisfaction with the police. Alternatively, it might also be interpreted as a good sign in that there is now a good protective system for making complaints effective, without adverse effects on the legitimate complainant. For an excellent article on this topic see Grabosky (1996).

\section{Suggestions for Implementation of Corporate Governance}

Having suggested what does not work we now consider what does. The first prescription would have to be to avoid that which does not work. Having said that there are several positive approaches that we might use, the first of which is to appeal to reason. These rational arguments might be divided into three broad categories.

The first category is in-house to the organisation. This will include addressing employee concerns, improving morale, avoiding debilitating internal criticism, and having the measurable qualities of decreasing absenteeism, and of improving productivity as well producing $\mathrm{s}$ a better-motivated force. It is also highly likely that it will both attract and retain better staff.

Another principle that the present author believes has much to commend it is that of what we might Gradualism (see Francis, Gius, \& Coin, 2004). Here the notion is not to be intransigent and immediate; not to be too pressing nor too inflexible but, rather, to have a longer-term goal in mind. To take a commercial example: one might deal with product from (say) India. Where a group of families in a village have a small commercial enterprise they might provide an economic commercial product, but do so using child labour. That issue is not always clear-cut; for example, the family and village are socially cohesive and provide excellent emotional support for the children even though they work hard.

A police instance is one where (say) a policeman in early days of experience committed a tactical mistake - not too serious a one. Suspecting that a crime may have been committed let us suppose that such a new officer breaks into premises only to find the place empty. A more senior colleague could use that experience to build up the experience and confidence of judgement in someone in need of experienced guidance. 
We do need to recognise that values underlie all principles of governance. If one did not have expressed values and someone suggested a new principle for governance one would not know if it had any merit unless one had a reference point: ethical values are just such.

\section{Five strategic suggestions}

Given that the accepted values that underlie police work it is seemly to offer some strategic suggestions for continued improvement: these suggestions are:

\section{$1 \quad$ Rules of meetings}

There are basic procedural rules for policy making bodies, and those involved in other forms of corporate governance. Among such requirements are their duties, responsibilities, actions, measures of protection, and the accountability of those who exercise corporate governance. It is a truism that corporate governance is exercised mostly by decisions made at formal meetings. While it is recognised that many, if not most, meetings work on a consensual basis it is crucial that there be agreed rules by which problematic decisions are made and recorded. Such a process affords fairness, economy of time, and a defensible position should any contentious points be raised at a later date.

It does deserve emphasis that compliance with formal requirements is necessary, but not sufficient. Formal rules are there as a guide, and capture the collective experience of what works: that function is aided immeasurably by the addition of goodwill to others and good intent of purpose. We do need to recognise that rules help us deal with contentious situations: as such they are of great value but not if the rules are used as weapons rather than as tools.

\section{Strategies}

Like Clausewitz on war or Machiavelli on politics, the master organisational strategist will always have in mind the means by which their aspirations might best be achieved. Anthony Jay in his Machiavelli and Management (1980), and by von Ghyczy et al (2001) in Clausewitz on Strategy are prime instances. Jay took the principles from The Prince and gave them application to modern management: Ghysczy took the Clausewitzian principles of military strategy and extended it to the econo-political realm. So long as we bear our values in mind there is much to be learnt from master tacticians. Knowing what works in implementing values, knowing the dangers and appreciating strategic approaches is crucial. Mission statements and the clear expression of values keep us focused. One suggested set of organisational objectives is: preventing crime, protecting individuals and organisations, keeping the peace, and catching the wrongdoer.

\section{Ethical infrastructure}

An infrastructure that demonstrates commitment to ethics would, at a minimum, consist of four features: a Code; an Ethics Committee; training in ethics; and regular reporting on ethical matters. Although this is no guarantee of ethical success it does provide both and effective approach and an indication of sincerity.

\section{$4 \quad$ Separate the issues from personalities}

One of the hard lessons that professionals learn is that of separating issues from personalities. Among senior experienced people it is commonplace to find polar opposite views on an issue while personal respect is still maintained. This division of view may be of various forms but, commonly, takes one of two views. One is an agreement of aims and principles but a difference in the preferred method of achieving them; the other is that of having vastly different views on a subject. The expression 'we will have to agree to disagree' portrays it nicely. Formal tuition for the less experienced could improve professionalism.

\section{$5 \quad$ Set criteria for success}

Finally, to make something work it is necessary to know what has worked: without markers of some kind one would never know. For this reason the criteria of judgement should be set out clearly and 
explicitly. Having the criteria is no guarantee, but it is an excellent start. For example, using the infrastructure instance above, an organisation with a Code of Conduct, a Committee which exercises it and suggests improvement, has a program that trains in values, and has regular reporting to command on its achievements is well on the way to success.

\section{Conclusions}

This paper argues for clear expression of the human values that underpin good codes of corporate governance. It is argued that such well-based codes benefit organisations in various ways. It is, in other words, an argument for the consequential view of ethics. When the agreed values are clearly expressed then, and only then, might we think about the strategies and tactics that would help achieve the agreed goals. Among the implications of this study are those of the value to police governance, to the wider issue of quasi-military organisations, application to firm hierarchical structures, and to governance in general. Issues, such as the 'rules of meetings', ethical underpinnings of governance, paradoxical cause, etc. all have general relevance. The suggestions offered may help move highly professional forces in appropriately governed directions: it is by a commitment to such developments and new insights that governance may progress not only in effectiveness but also in organisational and moral stature.

\section{References}

Devlin P (1963). Enforcement of morals. London: Oxford UP

Francis RD \& Armstrong AF 2006 Quantifying ethics. Australian journal of professional and applied ethics. Ethics 9(1)74-85.

Francis RD, Gius E and Coin R (2004). Ethical gradualism: a practical approach. Australian journal of professional and applied ethics. 5 (1) 25-34

Grabosky PN (1996). Unintended consequences of crime prevention. (in Homel and Clarke, Eds). Crime Prevention Studies. Vol 5 (1996)

Hart HLA (1987). Issues in contemporary legal philosophy. Oxford: Clarendon Press

Jay A (1980). Machiavelli and Management: an inquiry into the politics of corporate life. New York: Bantam Books

Von Ghyczy T, von Oetinger, B and Bassford C (Eds) (2001). Clausewitz on Strategy: inspiration and insight from a master strategist. NY: Wiley. 
